\title{
THE APPLICATION OF EGP MATERIALS TO ATC STUDENTS OF CASEA MAKASSAR
}

\author{
Agus Rahmat \\ rahmatppsunm14@gmail.com \\ Muawwal Al As'ary \\ arieliverpudlian12@gmail.com \\ Universitas Negeri Makassar
}

\begin{abstract}
The objectives of this research were to find out the application of English for Generic Purposes (EGP) materials to the Air Traffic Controller (ATC) class in learning English at Civil Aviation Safety and Engineering Academy (CASEA), Makassar and the students' perceptions toward the application the materials. This research employed descriptive qualitative research design. It applied cluster random sampling technique. The informants of this research were nineteen that consist of one lecturer and 18 ATC students of CASEA Makassar. The data were collected by observations and interviews. The observations were conducted to gather the data about the application of the materials to the students while the interviews were done to support and strengthen the data from observations whereas the interviews were also purposed for analyzing the students' perception toward the application of the materials. The result of this research showed that (1) the application of EGP materials to ATC students of CASEA Makassar was quite effective since the lecturer had various ways in teaching English and could teach the students based on their needs as aviation students and (2) most of the students felt that both ESP (English for Specific Purposes) and EGP were so beneficial for them since as aviation cadets, they are required to be able to communicate in English. Despite the necessities for learning EGP and ESP, most of the students contended that ESP was more essential in their working environments as aircraft controllers.
\end{abstract}

Keywords: EGP materials, ATC students, students perception

\section{INTRODUCTION}

English as the most popular language in the world becomes the most important intention by many people to learn. English looks as the essential subject in any educational unit, even becomes the priority in some countries like Indonesia. As educational practices in our curriculum, English has been a subject in elementary level, even earlier, such as kindergarten and play group. It is also for secondary level, in junior high school and senior high school. For university level, English is taught in all departments. Even though, English is only as the general subject for non-English major and taught only for several semesters.
English Language Teaching (ELT) can broadly be divided into General English or English for General Purpose (EGP) and English for Specific Purposes (ESP) (Hutchinson \& Waters 1987). EGP focuses on general English language abilities of students whereas ESP focuses on specific skills and needs of learners based on a detailed analysis of learners' professional/academic needs. Hutchinson (1987) stated that English language taught at school and college level is called EGP, and when it is offered to professionals like engineers and doctors and to the students like engineering students, medical students, it is tagged as ESP. Furthermore, Sajad $(2014,18)$ stated that the difference which makes ESP different from EGP 
from every point of view is concerned with the analysis of the needs of the students. What is needed is an essential component of the course which decides the entire design of the course.

In EGP, the focus is on teaching the common vocabulary and language structures and teachers are usually the only source of knowledge that is bombarding learners with structure that they are not or little familiarity. In fact, most of the problems that are relatively new for them. In ESP, the focus is on learner needs, expectations and why they need to learn this language. Here, in the context of language becomes important. Rationally, because the purpose of the changes to the learners, the context also varies to suit their needs. Unlike EGP learners, ESP learners knowledge of its context make it easier not only for them to participate actively in the learning process, but also their teachers to guarantee their effective teaching.

Based on some distinctions between EGP and ESP from previous researchers above, the researcher draws conclusion that what distinguishes EGP from ESP is an awareness of the needs. In addition, the distinction between EGP and ESP lies in the way we define and implement the learning purpose. While EGP is aim-oriented which does not equate the specification of objective to aim-an educational operation-dealing with the development of general capacity, ESP, on the other hand is objective-oriented learning where the specification of objective corresponds to the aim-the training operation-which deals with the development of restricted competence.

The researcher found an interesting phenomenon at Civil Aviation Safety and Engineering Academy (CASEA) Makassar. This institution is located in Maros, a neighboring regency of Makassar, South Sulawesi. CASEA Makassar is a college that is specialized in aviation such as air navigation and telecommunication, aircraft engineering etc. In CASEA, English is one of mandatory subjects that must be passed by the cadets, because as we know that English is very closely related to the aviation area. Therefore, cadets of CASEA Makassar are categorized as ESP students since they learn English for their needs in aviation and engineering. For CASEA students/cadets, learning English is quite comprehensive since the English as a Foreign Language (EFL) teaching and learning process should cover those two areas of English. They do not only learn ESP but also EGP. ESP is expected to be used in their work place some days, while EGP will be valuable to support it.

This research was intended to answer the following questions; (1) How is the application of EGP materials to ATC students in learning EFL at CASEA Makassar?; and (2) How is the students' perception towards the application of the materials?

\section{LITERARY REVIEW \\ Previous Findings}

Hafiz (2012) found that there are many common areas in ESP and EGP courses. They do not only share a common ground at lexical level but also in their contents, exercises, activities, lesson planning, teaching methodologies, use of $\mathrm{A} / \mathrm{V}$ aids, feedback, follow up and assessment criteria. These common grounds must be explored, and incorporated in designing language course of ESP and EGP. Meanwhile, Islam (2014) drew some distinctions between ESP and EGP practitioner. He stated that ESP practitioners have to show more flexibility in their approaches because of ever-changing teaching situations and autonomous students in ESP contexts. Both EGP and ESP teachers should be skillful and trained to produce fruitful results in their fields. But it can safely be assumed that ESP teachers must be given special training 
in the required skills like need analysis and material designing to enable them to meet the specific needs and high expectations of their students.

In contrast with the previous researchers above, Rajabi et. al. (2011) distinguish EGP and ESP based on the contents. They confirm that grammar is neglected in most ESP. ESP teachers do not try to explain functional elements of sentences and paragraphs like discourse markers and sentence organization. It is different with EGP teachers because they emphasize grammar, structure or English conversations more as the main courses in teaching and learning process.

The research findings of Rajabi are also in line with Dehghan (2012) which mentioned that ESP practitioners had fewer problems dealing with special content and vocabulary. Besides, ESP teachers were not successful to meet all language needs of the learners. Most of them just focus on the content. They rarely teach about grammar, parts of speech and linguistic features like EGP.

\section{English for General Purposes}

According to Hutchinson (1987), English Language Teaching can broadly be divided into two major types. They are general English or EGP and specific English or ESP. Mostly, the type is based on teaching itself wheteher the teaching specializes on general or specific materials.

EGP refers to contexts such as the school where needs cannot be readily specified. It is more useful to consider EGP providing a broad foundation rather than a detailed and selective specification of goals like ESP. (Hutchinson \& Waters 1987, 53-54). Further, they also confirms that EGP generally refers to the English language education at school levels where the students are made familiar with the structural/grammatical elements of English language to pass the exams.

According to Potocar (2002), EGP provides basic knowledge and skills of English language at a school level where the occupational/professional and higher educational orientations of the students are not defined properly. Meanwhile Mohseni (2008) states that EGP courses are planned to enhance students' general language competence for a more accurate and fluent production and reception of English in dealing with everyday situations. Also, one of the most important missions of EGP courses is to cultivate students' enthusiasm and habits in learning English.

Based on the definitions above, the researcher infers that EGP focuses on applications in general situations: performing in English on personal or social levels or using English in casual conversations and functions. In other words, EGP refers to contexts such as school where needs or the specific purpose in learning English itself cannot readily be specified.

\section{Features of EGP}

According to Hutchinson \& Waters (1987), EGP has some features which inflict them with English for Specific Purpose. The features are as follows:

1. EGP is essentially the English language education in junior and senior high schools.

2. EGP curriculum also include cultural aspects of the second language. EGP conducted in English-speaking

3. EGP learners are introduced to the sounds and symbols of English, as well as to the lexical/grammatical/ rhetorical elements that compose spoken and written discourse. There is no particular situation targeted in this kind of language learning.

4. EGP focuses rather on applications in general situations: appropriate dialogue with restaurant staff, bank tellers, postal clerks, telephone operators, English teachers, and party guests as well as lessons on how to read and write the English typically found in textbooks, newspapers, magazines etc. 
Based on some features of EGP above, it can be concluded that the application of EGP just focuses to improve the students' ability in English generally. So, the teacher does not categorizes the materials to be more specific. There is no particular situation targeted in this kind of language learning.

\section{English for Specific Purposes}

The definitions of ESP as conceptual term appeared in the literature only in the 1960s. Hutchinson \& Waters (1987, 19) approach to language teaching in which all decisions as to content and method are based on the learner's reason for learning. meaning that ESP does not involve a particular type of language, teaching materials or methodology.

Robinson $(1991,1)$ states that "ESP is a major actitvity around the world today. It is an enterprise involving education, training and practice, and drawing upon three major realms of knowledge: language, pedagogy, and the students' participants' specialist areas of interest." Meanwhile, according to Mohseni (2008),

ESP is an recognizable activity within the broader professional framework of English Language Teaching, with implications for the design of syllabuses and materials as well as its presentation and then evaluation. On the other hand, ESP is the way how to teach English with approximation method for specific purpose. It is not focus on the kinds of language.

It can be concluded that ESP brings into line what field the learners need. For example, English for doctors, lawyers, tourism and nursing, architecture, accountant, medical scientist, civil engineering, etc. Therefore, English will be taught differently among one field with others.

MacKay \& Mountford (1978), states that ESP refers to the teaching of English for autilitarian purpose (the purpose refers to the needs of learners in academic, scientific or occupational studies). In addition, Nunan (2004, 7) state that ESP is an important subcomponent of language teaching that has its own approaches to curriculum development, material design, pedagogy, testing and research. Meanwhile, according to El-Minyawi (1984) ESP courses are merely built on the need to convey the ideas (of subjects) which students need to be able to read confidently and speak about them fluently afterwards. Lastly, Potocar (2002) states that ESP can be viewed as a special and specific edition of EGP that incorporates practical linguistic skills to enable students for the successful performance of professional tasks.

According to Robinson (1991, 3), definition of ESP is based on two criteria: (1) ESP is normally 'goaldirected' and (2) ESP courses develop from a needs analysis which aim to specify what exactly it is that students have to do through the medium of English, and a number of characteristics which explain that ESP courses are generally constrained by a limited time period in which their objectives have to be achieved and are taught to adults in homogenous classes in terms of the work or specialist studies that the students are involved in.

Based on some definitions about ESP above, the researcher draw a conclusion that ESP is based on students' needs in learning English. Since students' needs in ESP are very crucial, needs analysis should be conducted earlier before designing the materials.

\section{Types of ESP}

According to Robinson (1991), there are many types of ESP with many acronyms. The two main types are EOP (English for Occupational Purposes), involving work-related needs and training, and EAP (English for Academic Purposes), involving academic study needs. EAP is one of the branches 
of ESP that helps engineers and technologists exchange technical information through technical English. The following are the detalis of both types of EAP:

1. English for Occupational Purposes (EOP)

EOP is taught in such a situation in which learners need to use English as part of their work or profession (Kennedy \& Bolitho 1984, 4). There will be differences in such courses depending on whether the learners are learning English before; during or after the time they are being trained in their job or profession. The content of an English program for someone actually engaged, for example, on a secretarial course with its acquisition ofpractical skills and theoretical knowledge-is going to be different from a program for someone who is already a qualified secretary but now needs to operate in English.

2. English for Academic Purposes (EAP)

EAP is taught generally within educational institutions to students requiring English in their studies. The language taught may be based on particular disciplines at higher levels of education when the student is specializing (in study) or intends to specialize (pre-study) in a particular subject. In cases such as an overseas student studying in university level, the learning of study skills (listening to lectures, taking notes, writing reports, reading textbooks) will probably form a major part of the student's English course (MacKay \& Mountford 1978, 7).

\section{The characteristics of ESP}

Peter Strevens' (1988, 1-13) definition makes a distinction between four absolute and two variable characteristics of ESP as follows:

1. Absolute characteristics

ESP consists of English language teaching which is:
- designed to meet specified needs of the learner;

- related in content (i.e., in its themes and topics) to particular disciplines, occupations and activities;

- centered on the language appropriate to those activities in syntax, lexis, discourse, semantics, etc., and analysis of this discourse;

- in contrast with General English

2. Variable characteristics

ESP may be, but is not necessarily

- restricted as to the language skills to be learned (e.g. reading only);

- not taught according to any preordained methodology

\section{Differences Between EGP and ESP}

Hutchinson (1987, 53) answers the question "What is the difference between the ESP and General English?" as "In theory nothing, in practise a great deal" which is very true because, in the $80 \mathrm{~s}$, teachers would rarely apply a needs analysis to discover what was really needed or necessary to be able to actually accomplish the objective. Nevertheless, nowadays, teachers are more conscious of the significance of needs analysis. Besides, teachers can now select materials which closely fit the aim of the learner. Maybe this shows the impact that the ESP approach has had upon English teaching in general. The basic distinctions between ESP and EGP can be drawn as follows:

1. Learners

ESP : specially designed for (working) adults

EGP : specially designed for high school students

2. Aims

ESP : the objective is to meet the needs of particular learners

EGP : to improve overall English competence involving a range of skills (reading, writing, speaking, listening, vocabulary, grammar, pronunciation, etc.) 
3. Concerns: sphere of interest

ESP : to design suitable courses for different types of groups oflearners inaccordance with their needs

EGP : designing courses targeting vocabulary work, spelling, grammar, pronunciation,language function etc.

Based on Hutchinson elaboration towards the difference of EGP and ESP above, the researcher assumes that the distinction betweenboth of themcan be considered by the needs of the learners, the learning objectives or goals of the learners and the learners' different area in earning English. Meanwhile, Mohseni (2008) formulates some important points about the general distinctions between EGP and ESP. The differences are as follows:

1. Learners and purpose of learning; ESP learners are usually adults who already have some familiarity with English learning and they are learning the language in order to communicate a set of professional skills and to perform particular job related functions. While in EGP classes, age of learners are varies from children to adults and learning English as one of the subjects in the classes.

2. Based on purposes of learning, aims of instruction are identified; in an EGP class, as a general rules, the four skills are stressed generally. They are listening, speaking, reading and writing. But in ESP class, it is needs analysis that determines which language skills are mostly needed by the students, and the syllabus is designed accordingly. For example, in order to train a tourist guide the ESP class should promote the development of spoken skill. Another example, one who intends to work in business administration should be trained in development in reading skill.

3. In a typical EGP classes, there is concentration on teaching grammar and language structures (mostly in isolation). But in ESP, the focus is on context. In ESP class, English is not taught as a subject separated from the students' real worlds/ wishes.

Language in Context > ESP

Language in Isolation $>$ EGP

4. Combination of subject matter (which learners are familiar with) with English language create a meaningful context which is highly motivating. This meaningful context increases motivation that is a positive indication of a successfull learning.

5. Regarding the term 'specific' in ESP, it should be noted that not only does it mean he English for specific purpose, i.e. English language at service or specific purposes, but e throuh a field that is already known and relevant to it. Therefore, learners are able to use what they learn in ESP classes right away in their work and studies. This means tat ESP enables them to use the English they know to learn even more English.

In conclusion, the researcher concludes that ESP assesses and analyzes needs and integrates motivation, subject-matter and content with the help of relevant language skills.Aside from the rough separation at the definition level, there is an overlapping connection and proportion between them. In order to clarify their relation Widdowson (1983) establishes distinctive features of ESP and EGP

The most important EGP features are:

1. The focus is often on education

2. As the learners' future needs are impossible to predict, the course content is more difficult to select

3. Due to the above point it is important for the content in the syllabus to have a high surrender value.

Meanwhile, the most relevant ESP features are: 
1. The focus is on training;

2. As English is intended to be used in specific vocational contexts, the selection of the appropriate content is easier;

3. It is important for the content in the syllabus to have a high surrender value, most relevant to the vocational context;

The aim may be to create a restricted English competence.

\section{RESEARCH METHOD}

In this research, the researcher employed descriptive qualitative research to find out the answers of the research questions as stated on the previous chapter. This research deal with analysis on the application of general English materials for ESP students program. Therefore, the researcher gathered and described the non-numeric data based on the phenomena. The researcher described how the application of EGP materials in learning EFL to ATC students of CASEA Makassar is and how the students' perception towards the application is.

\section{Research Subject}

The subjects of this research were the second year cadets/students of CASEA Makassar at the third semester in academic year of 2016/2017. There were three classes with total 75 students. The classes consist of Air Traffic Controller (ATC) class, Telecommunication and Air Navigation (TAN), and Flight Service Officer (FSO) class. The technique of gathering the sample was cluster random sampling, and took ATC class students and their lecturer as the research subjects.

\section{Data Collection}

The researcher applied descriptivequalitative research design. Nevertheless, in supporting this research, the researcher used two instruments namely observations (by using note-taking) and interviews. The observation instrument was used to find out the data related to the application of EGP materials for ATC class by observing the English teaching and learning activities at CASEA. Meanwhile, the interviews were conducted to find out the data from students about their perception toward the application of the materials. The data of this research was taken on May 18, 2016 until May 30, 2016 at the third semester of 2016/2017 academic year. The cadets of ATC batch 3 of CASEA Makassar were selected as the sample of this research.

\section{RESUlTS AND Discussions}

\section{The Application of EGP Materials}

In the classroom observation, the researcher found that the lecturer's way in teaching EGP was various and interactive. The lecturer treatment in teaching was different from the class generally because the students' main need is English aviation. Look at the observation results below:

In the first observation, the lecturer taught some tenses and grammar. In delivering the materials, he taught them by Question and Answer strategy to create an active atmosphere in the classroom. Further, the lecturer tried to put some ESP elements in his EGP materials by giving some vocabularies and sentences that related to aviation area. It's aimed to make the students learn by their needs because nevertheless, aviation students should learn English for aviation.

In the second and third observation, the general English lesson was taught in listening section. Besides speaking skill, listening also became focus in learning English at CASEA, especially for ATC students, because speaking and listening are very crucial for controller in navigating and communicating with pilot. Therefore, listening has bigger portion to be taught for ATC students.

In supporting the data from observation, the researcher also took some data from lecturer's interview. Look at the statements below: 
$1^{\text {st }}$ statement

(R: interviewer, E: interviewee)

$\mathrm{R}$ : I want to ask about the application of EGP materials to ATC cadets. In your opinion, is the application of EGP materials can be effective to improve the English skill of ATC cadets?

E : Oke, I got it. In CASEA, both of EGP and ESP are very important to be learned. I can't deny that ESP becomes their main requirement to be aviation students because it's used in their working area. However, based on my experience while teaching here, EGP materials that they have learned can't be neglected because it's very helpful in learning ESP itself because most of the CASEA manual books use English. So, if you ask me about the effectiveness of learning EGP for CASEA cadets, my answer is surely yes

\section{$2^{\text {nd }}$ statement}

$\mathrm{R}$ : How about your way of teaching sir? I mean, ee how do you apply EGP materials in your class? Do you only teach English generally or sometimes you also teach ESP?

E : In ATKP, I just teach general English or EGP, but I realized that those cadets are categorized as ESP students or aviation students. That's why, the EGP materials that I applied to them sometimes combined by some ESP elements. For instance, when I teach tenses, the examples that I give is related to their area. I also always give them some vocabularies that related to aviation to increase their comprehension in English aviation.

Based on the observation class and lecturer's interview, the researcher drew some statements that the application of EGP materials must be appropriate with the students' needs. That is why in the teaching process, the lecturer sometimes put some ESP elements in his English materials for his students. He also always makes efforts to use terms or vocabularies that related to aviation. It is aimed to habituate them to learn English based on their needs. In addition, the lecturer concluded that however, ESP is still more essential than EGP ATC cadets because they are categorized as ESP students. The role of EGP here as the supportive materials that can help the cadets in learning ESP.

Students' Perception toward the Application of EGP Materials

The followings are the data from the interviews.

\section{$1^{\text {st }}$ informant}

$\mathrm{R}$ : So, do you think EGP or general English materials useful for your major in aviation?

E : Yes sir.

$\mathrm{R}$ : What's the benefit for you?

$\mathrm{E}$ : The benefit is eee.. for instance when we are controlling, we dominantly use general English sir. And, sometimes the EGP materials that we learn is exist while we are in controlling duty.

The first informant is AK. Based on the interview, he stated that learning general English or EGP is very useful for his future. The main reason is an ATC should be fluently in speaking English because the communication with the pilot mostly use English. While he also said that EGP is very essential to be learned because one of requirements to get ATC license from CASEA is TOEFL score. The cadets should pass the TOEFL score which determined by CASEA to get ATC license. Therefore, according to the informant, learning EGP or general English is so beneficial for them.

\section{$14^{\text {th }}$ informant}

$\mathrm{R}$ : What makes it useful anyway?

E : Because EGP and ESP are supporting each other Sir. Whether for communication between aircraft 
crews or foreigners. Moreover, if we want to pass the Air Navigation, we should have high TOEFL score, Sir.

The fourteenth informant is. Based on the interview, she states that the application of EGP in ATC class is effective enough. Further, she thinks that as a controller, ESP will be used dominantly rather than EGP. Nevertheless, general English or EGP is still beneficial for her because it can support her ability in mastering English.

\section{$15^{\text {th }}$ informant}

$\mathrm{R}$ : Based on your opinion, do you think that the application of EGP materials like tenses, grammar, passive voice,etc useful for your future in aviation?

E : Yaa, I think, eee... it's absolutely useful sir. Because foreign language especially English has very tight relationship with aviation. Despite, we can't deny that ESP is used more dominantly in aviation but at least EGP can support it.

\section{$16^{\text {th }}$ informant}

$\mathrm{R}$ : So, eee... do you those kinds of material effective for your major in aviation?

E : I think general English or EGP is tend to be learned for ee daily life sir. While for my major in aviation, specific English is more often to be used.

$\mathrm{R}$ : So do you think the application of general English or EGP useful for your major in the future?

$\mathrm{R}$ : I think it's absolutely useful sir because ee.. an aircraft controller has bigger chance to work abroad. So if we have partner or crews from overseas, we won't have difficulties in communication because we can speak English fluently.

The sixteenth informant is RF. Based on the interview, he states that EGP and ESP have different utilization. He argues that EGP is used for communication in daily life or daily conversation while specific English or ESP is used in specific area, includes aviation. Despite ESP becomes focus in aviation, he considers that EGP is still important for controller. Further, he contends that as anaircraft controller, he must be ready to work in abroad. That's why he thinks that he won't face difficulties in abroad if he can speak English.

\section{$18^{\text {th }}$ informant}

$\mathrm{R}$ : So, the application of EGP materials is beneficial for your major in the future. Isn't it?

E : Eee ... Maybe it's not too crucial sir but at least it can support us in learning ESP. If we compare both of them, ESP is surely more important than EGP.As the matter of fact, we haven't learned ESP intensively so I can't decide which one is more effective sir. But I think it's much better if we are able to learn both of them.

The eighteenth informant is $\mathrm{S}$. Based on the interview, he said that for aviation students, learning ESP or technical English is exactly more necessary than general English. However, he states that EGP can help him to learn ESP itself. Therefore he concludes that learning both ESP and EGP becomes necessities in aviation.

\section{Discussions}

Based on the English classroom observation in which applied by the researcher at ATC class of CASEA Makassar, it is found that the English teaching and learning activities in ATC class was various and effective. The application of EGP materials at ATC class was not monotonous because the lecturer taught them with various methods and sometimes intercalated by some games to build good atmosphere in the classroom.

Specifically for general English, the lecturer taught them in various ways and method. In the first observation, the lecturer taught some tenses and 
grammar. In delivering the materials, he taught them by Question and Answer strategy to create an active atmosphere in the classroom. Further, the lecturer tried to put some ESP elements in his EGP materials by giving some vocabularies and sentences that related to aviation area. It's aimed to make the students learn by their needs because nevertheless, aviation students should learn English for aviation.

In the second observation, the general English lesson was taught in listening section. Besides speaking skill, listening also became focus in learning English at CASEA especially for ATC students because speaking and listening are very crucial for controller in navigating and communicating with pilot. Therefore, listening has bigger portion to be taught for ATC students.

In supporting the data from observation, the researcher also took some data from interview. The researcher interviewed the lecturer and some students to compare the data from observation and interview whether they are parallel or not.

Based on the informants interview, the application of EGP materials at CASEA Makassar, especially for Air Traffic Controller cadets, is quite effective. In learning English, CASEA cadets includes ATC are required to learn both ESP and ESP. Learning ESP is aimed to help them in work place in aviation, while EGP will be valuable to support it.

It can be concluded that the application of EGP materials for ATC students at CASEA Makassar was quite effective because the lecturer taught them based on their needs. The lecturer made effort to give EGP materials that appropriate for their area in aviation. Therefore, learning EGP for ATC students at CASEA Makassar cannot be neglected because it's valuable as supporting materials in learning ESP.

By administering interview to students, it is found that hat most of
ATC students at CASEA Makassar contended that the application of EGP materials in learning English in their class is beneficial. Most of them stated that learning EGP is very helpful in aviation area which requires them to be able in English.

\section{Conclusions AND SUGGESTIONS}

Based on the findings and discussionss in the previous chapter, the researcher determines forward the following conclusions:

1. The application of EGP materials for ATC students at CASEA Makassar was quite effective since the lecturers have various way and teaching English and taught them based on their needs as an aviation student.

2. The English learning process in CASEA Makassar divided in two areas namely EGP and ESP. Learning EGP for aviation cadets should only be supportive materials for proficient ESP, because in the field, ESP will be used more than EGP. Therefore, EGP should only provide basic knowledge for applying ESP. All cadets of CASEA Makassar stated that learning both ESP and EGP is so beneficial for them since as the aviation cadet, they are required to be able in English. Despite the necessities for learning EGP and ESP, most of the students contended that ESP is more essential in their working environment as aircraft controllers.

Considering the conclusions above, the researcher further states some suggestions as follows:

1. For any vocational institutions including CASEA Makassar, it's recommended to not give the same portion of materials between ESP/technical English and EGP. Learning EGP for aviation cadets should only be supportive materials for proficient ESP, because in the field, ESP will be used more than EGP. Therefore, EGP should only 
provide basic knowledge for applying ESP.

2. In delivering EGP materials for vocational students, the lecturer should provide the materials that familiar with the students' area. For instance, teaching EGP materials for aviation is recommended to provide materials that related to aviation area.

\section{REFERENCES}

Harati, R. Dehghan 2012. "Personal Observation of Three ESP Classes". The Iranian EFL Journal. 8 (1): 318-333

Hafiz, Kasim. 2012. Identification of Common Cores in EGP and ESP, EuroJournals Publishing, Inc.

Hutchinson, T \& A. Waters, 1987. English for Specific Purposes: A Learningcentered Approach. Cambridge: Cambridge University Press

Islam, M. 2011. "The Differences and Similarities between English for Specific Purposes(ESP) and English for General Purposes (EGP) Teachers". Asian EFL Journal. 10 (4): 211-226

Kennedy, S \& R. Bolitho. 1984. "The Role of Writing in Graduate Engineering Education: A Survey of Faculty Beliefs and Practices". English for Specific Purposes

MacKay, R \& A. Mountford (eds.). 1978. English for Specific Purposes: A Case Study Approach. London: Longman

Mohseni, Mohammad. 2008. "On the Relationship Between EGP and ESP: A
General Perspective". Asian EFL Journal, 10 (4): 211-226

Nunan, David. 2004. Task-based Language Teaching. Cambridge: Cambridge University Press

Potocar, M. 2002. "ESP in Slovenian Secondary Technical and Vocational Education”. English for Specific Purposes World. 1 (online): $<$ http://www.espworld.info/Articles_1/es p.html>

Rajabi, P, GR. Kiany \& P. Maftoon. 2011. "Iranian English Major vs Suject Matter ESP Teachers Beliefs and Instructional Practices in ESP Classes: A Comparative Study" in First International Conference on Foreign Language Teaching and Applied Linguistics (FLTAL) 11-2011. Sarajevo

Robinson, P. 1991. ESP Today: A Practitioner's Guide. Hemel Hempstead: Prentice-Hall International

Sajad, D. et. al. 2014. "Observation and Feedback of Content Specialists versus General English Teachers: Suggestions to Make Optimal English for Specific Purposes Courses". Journal of English Language Teaching and Learning. 13

Strevens, P. 1988. "ESP After Twenty Years: A Re-appraisal" in M. Tickoo (ed.). ESP: State of the Art(1-13). SEAMEO Regional Language Centre

Swales, J. 1988. Episodes in ESP. Prentice Hall

Widdowson, HG. 1983. Learning Purpose and Language Use. Oxford: Oxford University Press 